\title{
Rhetoric Tradition and Democracy: Isocrates' Role in Ancient Greek Political Idea. Start Point of Western Political Philosophy
}

\author{
Mehdi Shokri
}

Department of Politics and Department of Philosophy, Free University of Berlin, Germany

Fellow of the Konrad-Adenauer-Foundation

\section{E-mail: Shokri.Phil@gmail.com}

\begin{abstract}
:
Political participation and the public education that have always been deployed to support the incipient progress of the civic life are revived in the modern political discourses. It has been believed that the age of pre-Socrates was the age of the Sophists whose acrid fallacy works occupied the political sphere, a malaise in government. However, speaking nontraditionally in the modern pedagogical system, there were some pre-Socratic thinkers and political philosophers/orators who's works are the backbone of modern discourse on this matter. It will be examined whether any part of the classical rhetoric apparatus can be recovered and put to a good practice in the modern education and modern political participation. This point will be illustrated, furthermore, in this paper by alleging the importance of rhetoric, its role in Ancient Greek Democracy, and its influence on the modern concepts of power and democracy, as a continual element in a historical-political life. The further consideration is whether there was any democratic Polis existed in Ancient Athens and then, if there was, what characteristics it consisted of. Moreover, whether such concept can or should be considered in modern political discourses. In this sense, the liberal, nondogmatic strain of the sophistry of Isocrates tradition urges us to indicate that the findings of this educational principles are, if not necessary, but adjutant complementary metes to our modern political knowledge of the states. In the end, it is inquired to see comparatively that how the tradition of rhetorical art and the concept of power in the Ancient Greek society have pertained to the modern democratic elements and whether we are able to empower this influential element in modern states.
\end{abstract}

Keywords: Isocrates, political power, political rights, virtue, democracy, rhetoric, education

[t]he "highest kind of rhetoric [is] that which deals with the greatest affairs and, while best displaying the ability of those who speak, brings most benefit to those who hear."

Panegyricus, 4

\section{The Sophists: Ambitious, Greedy, and Neglecting the Truth}

After the Homeric period and before the well-known appearance of Ancient classical philosophers, an important turning point had taken place in the Athenian society. It was the political participation of the majority, or at least a benevolent intention to do so. In such changing culture that gradually 
placing the rights to participate in the public debate in the hand of the many rather than the few, sophistical rhetoric presented through the appearance of the sophists was a valuable skill and a useful instrument that both part of the power, one was the mythic aristocrats and precipitous democrats could use profitably. Some have argued that Sophistical movement of the $5^{\text {th }}$ B.C. century was turning point, which occurred against those natural philosophers who were solely concerned with the ultimate substance and atoms, and bewildered by the nature surrounding them. This interpretation is plausible, yet the point is that the amusement continued till the pre-Socratic philosophers all began to overlook the nature of human beings. That is why we see some strong opposition against that change from the thinkers in that period and before.

Protagoras's great achievement is to illustrate that the measure of all things is only a human being [35], 152a , [38], 14:28-29. And it is likely to say that, that was a turning point, which happened in that period to bring the attention of his contemporaries away from nature and toward man himself.

It was with this movement that most of the constitutional thoughts about human beings changed too. Within this movement, the primary consideration was the excellence of human beings. Arête, because of its transitive state, has not remained as it was viz. merely a notion of bodily function, but was considered essential to political participation. Thus, it literally became an indication of good character [32, pp. 27-31]. With the gradual growth of political life in Athena and the growing desire for more civic education, the first generation of the sophists was more concerned with being successful in the popular realm of society, but still there was a significant difference among the proposed explanations on the idea of Arête. Being successful became a cornerstone of every political activity, so the virtue of a person as well as a citizen was regarded as an excellence and as a power with which one could win the political debates.

\section{Ethical Value of Arête: Pre-Socratic Philosophers and the Fifth Century Enlightenment}

The tradition of seeking truth through the strategic methods began subtly in the fifth century, but political considerations changed the overall tendency to what ethical notions should be about. Plato, in one of his famous dialogues, mentioned Protagoras [20] as one of the first teachers, among whom I call them First Generation of Sophists, e.g. Gorgias, Prodicus, Hippias, Thrasymachus, Lycophron, Callicles, Antiphon, and Cratylus. He was primed in turning the attention of the philosophers from Nature to the human beings, through the highlighting the facility of language. Protagoras extracts the domain language in craft and entered it in the political wisdom [37, p. 187]. He believed that he taught an art to young men $\left[11,316^{\mathrm{b}}\right]$ with which they were being able to arrange their own lives and could participate in public life through their deeds and words [18]. The idea behind that is the relation between the skills in using the language and the skill in understanding the principle of the justice, which is correctly highlighted by him, is the power $(\varepsilon \xi$ ov $\sigma i \alpha)$ in itself in every democratic state:

the one who studies with me will learn to exercise sound judgment in political affairs, showing how he may be most powerful $(\delta v v \alpha \tau \omega \tau \alpha \tau o \varsigma)$ in conducting the business of the city both in speech and action $\left[11,318^{\mathrm{e}}-319^{\mathrm{a}}\right]$.

With more focus on the word ' $\delta v v \alpha \tau \omega \tau \alpha \tau o \varsigma$ ', one of the most interesting combination of the physical power and the capability of non-physical power in human being, which is the ability to speak, appears $[39$, p. XV]. The recognition of such capability may be the first indicator of the concept of 'power to'. The potentiality of the speaking is requires not only the physical practicing but also non-physical one in the manner of rhetorical skills which focus on the one's capability to affect based on her autonomous will. As the consequence of this ability, the phenomenon of political debates emerged which contributes to the political power and democratic process. 
However, Isocrates stressed that his teaching is practical and is aimed at preparing young men to be the gentleman [33, p. 4]. Here, the common essential character of the rhetoric and the political participation were highlighted by the Isocrates were he argued more concretely than Protagoras on the active political role of the individuals. In this sense, the act of correct sophistical movement was to prepare others the political, legal and social issues of their states effectively. Moreover, it was a huge contribution to the civic education. Based on the principles of liberal rights, it is arguably one of the main foundations of a democratic state. The focus in the period of the first generation of sophists was on the affairs of the Polis, or the state. The intense political activities of the sophists and the usefulness of the rhetorical skill is esoterically implemented in the Callicles' critics of the philosophers, where he exaggeratedly highlights the difference between the rhetorical and philosophical tradition in respect to the state's political affairs:

If a man is exceptionally gifted and yet pursues philosophy far on in life, he must prove entirely unacquainted with all these accomplishments requisite for a gentleman and a man of distinction. Such a man know nothing of the laws for their cities, or of the language they should use in their business association both public and private with other men, or of human pleasure and appetites, and in a word they are completely without experience of men's characters. And so when they enter upon any activity public or private they appear ridiculous [11, Gorgias, $\left.484^{\mathrm{c}-\mathrm{d}}\right]$.

However, the spirit of true political activity was ruined by the theme of becoming popular merely through rhetorical skills. Thus, the political activity took the fated road. It became popular for each person who was able to skillfully and persuasively convinces others about the unjust ideas, using 'the tricks' of rhetoric and consequently win the debate, without considering what the characteristics of that debate really consist of. It was in this point of view that Isocrates criticized the Sophists. Since they "value all of moral excellence and happiness so little" [22, I. 4] to gain the fame and money through social victories. Moreover, with social victories, albeit small, one was able to gain rights and honors. Those who gained more victories in the speech-fights over important social matters regarded as famous and popular figures. This area of activities is specified as, and I shall call it, the activities related to the Second Generation of Sophists. It was in this period that the focus of the sophistical movement changed from the affair of Polis to the affair of the mind. Indeed, the tradition of seeking the truth in both Ethical and political activities separates the first and second generation of the Sophists.

\section{Revolution of Socrates: Transitioning from natural Thought to Moral Thought}

While, the second generation of the sophists was busy with their political activities and was scrimmaging around for success in political debates; the ethical notions and values were merely presented in words, but not in deeds. "To the sophists, however, virtues and truth were negligible considerations. Their efforts were bent on a display of rhetorical virtuosity" [3, p. 24]. This method, rather than a strategic, is the tactic one, which is more relying on the opportunities for reaching the foundation of power, cf. [36, p. 50]. Here, we can see that the concept of 'power to' as an ability and the concept of 'power of' as an act based on the autonomous will and scoop of capability produces a democratic recognition in incipient political societies. However, there were some other thinkers who searched for the truth. They had a different ideas and perspectives toward the knowledge and power, and the way to convey it to the others through rhetoric. Unlike the second generation of Sophists, they started with metaphysical issues like 'knowing the world outside of us'. They were concerned with discovering the truth, whether it was material or immaterial. Then, in this direction, they moved back more toward the human soul in the age of 'political participation fever'; namely Prodicus ${ }^{i}$ and Heraclitusii. This movement, at this time, was based on the place of the human beings in metaphysical view according to the links between human's intellect, the place of 
Logos and the place of truth. Such concept is empowered by the recognition of Logos and its role in socio-political life.

As debates over nature lost steam, Human-affairs' debates gained in strength. Socrates was the first one, who considered virtues and other Ethical-rational notions in their real senses. Through his endeavors in ancient Athenian society, the period of ignorance - which was based on the idea of deeds for the sake of fame and religion - was surpassed. Socrates was not completely successful against the other opinions of his society, as many of those opinions took their strong account from the traditions and the history. Nevertheless, he was the pioneer of a long road, which is still evident today in our modern society.

Socrates was the first thinker that claims that one act foolishly and wickedly since he does not 'know' what is best for him. Thereby, the political debates have been considered ever since, by most of the thinkers after him, more seriously and more concretely on the normative analytical way. Since Socrates' period on, most of the ethical virtues such as friendship, valor, honesty, just, and discipline have been reinterpreted, constantly respected as it should be under the practical wisdom category. The concept of such virtues in the sixth century and early fifth century B.C. differed notably from the earlier periods, but in some aspect, footsteps of the earlier concepts still can be seen in the changed Socratic period. In this view, we can regard this transition as the gradual inner revolution of ethical notions.

Some important interpretations of Ancient Athenian works, for instance, Alasdair Chalmers Maclntyre, Julia Annas, Geneviere liyo and Terence Irwin, are now garnering attention. It seems that the concept of virtue, in Ancient Greece, was not as shallow a notion as had been previously

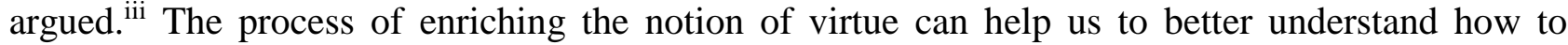
analyze the notion of virtue in respect to the time. There were 4 important elements to this conceptual and practical change:

(i) Poems and tragedies of Homer,

(ii) Rhetorical skills of sophists

(iii) Skeptics thinkers

(iv) Classic Philosophers, e.g. Socrates, Plato and Aristotle.

Ancient Greek philosophers stressed virtue as a goodness of the human's soul. They believed that virtue must be realized and practiced throughout one's life. Virtue, by its very nature, should not remain merely a theoretical doctrine, but also must be considered in a practical way, since its essence is intrinsically practical. Realizing the good and acting in accordance with the virtue that aims at good indicates that the very usage of virtue, not only limits the function of theoretical wisdom, but also relates to function of practical wisdom, i.e. the power of legislation (for both moral agent and political community), and the power of carrying it out in an individual way of life as well as in a social way of life by both individuals' will and by political authority.

Despite that virtue is the cornerstone of Virtues Ethics; the defenders of this branch of ethical philosophy have not presented the exact interpretation of virtue. We shall not concern ourselves with the differences, but we will consider their common points. What they all have in common is the fact that virtue is connected to the habit and ration and can be flourishing in the human's soul. It is not deniable that the flourishing of the human's soul, according to this concept of political-ethical philosophy, is impossible without the social way of life, i.e. active political life in Polis. Thus, virtue is one of the main and necessary elements of having a good city-state.

\section{Overview of pre-Plato ambiance: Isocrates}

It is a commonly held belief that modern political philosophy should be traced back to the schools of Ancient Greece. Most of the research, produced by modern academics is focused on those ancient Greek philosophical schools of Aristotle and the schools of Plato and Socrates. But as I argue, there are other influential thinkers, philosophers, and 
statesmen who played important roles in forming and enriching the ideas of ethics and politics in ancient Greece. I allege that Plato's thoughts, especially in politics, trace back, not only to Socrates but also to pre-Socratic political thinkers like Isocrates.

Indeed, because of the public fever for political participation, by the end of the fifth century B.C., any so-called political structure based on the merit and elites person were unambiguously carrying notions of unjust and illegitimate one. To be more specific about the opponents of these structures, we have to say that the whole mass tried to fight against it and to establish a participatory authority of the demo in which all of the people can be a part, viz. the government, which is of the people, by the people and for the people. This is the only sort of government that guarantees the desire of the demo due to its knotted foundation with its subjects as its body. But that was not how philosophers like Plato and Aristotle ideologically wanted to establish their Utopia and Polis.

However, there was another, not completely, opposite trend can be traced at the end of the fourth century B.C. by one of a younger contemporary figure of Socrates called Isocrates. Parallel with Socrates, Isocrates was the first person who talks about the same erudition that Socrates does, but with more focus on the ability of the rhetoric skills, its role in a specific political situation and the worthwhile ends it can achieve. Hence, there is a strong common point between Isocrates and Greek philosophers in the foundation of humans' affair that can be traced through the Socrates of Plato, and then Aristotle's thoughts.

\section{Orator or philosopher}

As I have previously depicted, in our historical approach to the ancient Greek revolution of thought and the socio-political life: the ability to speak, was i) related to the excellence of the body, the concept of 'power of' ii) at the top among the skills and excellences, the concept of 'power to' and iii) man could gain it to be successful in all aspects of his civic life, the concept of 'power over'.

Due to the political participation fever in newfangled democracy in Athens, it was up to each individual's power of speech to be successful in social-political participation, which took place in the context of debates. It was for the first time that the multitude, regardless of being noble, blue blood or rich, had a chance to make their voice hear effectively in the public debates and more importantly, in political decision-making. Therefore, it was necessary for people to be familiar or even be an expert in the art of speaking. Through "technical rhetoric", their demands if well-presented could get a good response from the society although not everyone could make it. Senators who were skillful in rhetoric and could present their point effectively often achieved success and celebrity status [10, p. 12], [23]. This skill continues to be important in high-level political debates, social-political spheres, as well as in many judiciary and economic institutions. In a sense, anyone who was skillful as an orator was essentially carrying a secret weapon that could bring him full success in all aspects of his social endeavors. Thus, what made Athens a rhetorical society, parallel to a democratic society, was its scope and goals of persuasion. In this way, rhetoric served as the most important capability to effect for individuals in the Ancient Greek Polis, an instrument to get into the power position.

Later on, the Athenians became more concerned with two aspects of logos: influencing human thoughts and direct intended effects on human actions. For being familiar with this tradition, we have to take a quick look at the starting-point of it. 


\section{Heraclitus}

Heraclitus is a pioneer in the tradition of surveying the Logos and its place in human life. The Logos, since then, became a cornerstone of the Ancient and medieval philosophy. What made Heraclitus' thoughts unique among his fellow philosophers in the pre-Socratic period was his method for seeking the truth and examining it thoroughly. Although he remained concerned with the problematic points of his predecessors regarding the philosophy of nature, he also stressed the importance of human nature and the role of human beings. Upon the publication of the Fragments [29], Heraclitus argued in the I (D.1, M.1) Sextus Empiricus, Adversus Mathematicos VII. 132 that $\boldsymbol{\tau o \boldsymbol { v }} \boldsymbol{\delta} \boldsymbol{\varepsilon} \lambda \boldsymbol{o} \boldsymbol{\gamma} \boldsymbol{o} \boldsymbol{\tau} \boldsymbol{\tau} \boldsymbol{o v} \boldsymbol{v}^{\prime} \boldsymbol{\delta}$

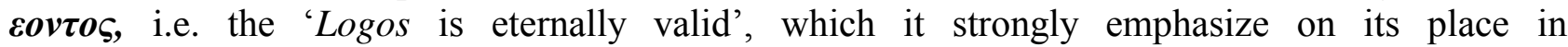
human life as well as the cosmos. The characteristics of its essence were effective also

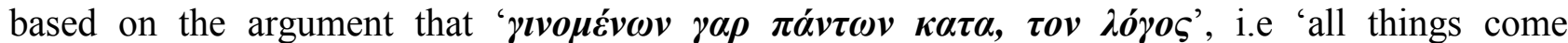
to pass in accordance with this Logos.' One likely interpretation that focuses on highlighting the elements of this fragment is to overweight notion of the $\boldsymbol{\pi} \alpha \boldsymbol{v} \boldsymbol{\tau} \boldsymbol{\omega} \boldsymbol{v}$ (pánton: of all things), ${ }^{\text {iv }}$ which I argue, that has a strong relationship, on the one hand, with the intellect, and on the other hand, with the natural law. Although, not relying on the traditional and famous translation, we can find the opportunity to focus on the $\boldsymbol{\kappa} \alpha \tau \boldsymbol{\alpha}$ which not only means "in accordance with", but also can be translated to "through", "down from" and more importantly as "per", which shows the Logos as an origin and as the end. The importance of this point of view implies that relation between the Logos and the intellectual activity of the political beings.

Within this context, Heraclitus challenged other thinkers to consider the nature of the human beings and his role in accordance with the Logos and the importance of the Logos in the personal and political life.

Speaking with understanding they must hold fast to what is shared by all, as a city holds to its law, and even more firmly. For all human laws are nourished by a divine one. It prevails as it will and suffices for all and is more than enough [29, XXX (D. 114, M. 23a) Stobaeus III.1.179].

Yet, the question remains, how does the idea of the Logos leads human beings to conclude that their role is more important than they had previously thought?

One of the most famous fragments of Heraclitus is:

Over those who step into the same river, different and different water flows [28, p. 52], [14, p. 471].

Remarkably, the dominance of nature and its characteristic of change was the center of attention for pre-Socrates' philosophers, and obviously with no exception for Heraclitus. Indeed, the matter of change is one of the important elements in the metaphysical idea of Heraclitus and his fellow philosophers. After the age of Heraclitus the idea of returning to the logic and denying all the perceptual sense of human beings began with the exaggerated interpretation of "the movement and the change" doctrine that pre-Socratic philosophers, such as Parmenides and Zeno of Elea (c. 490 - c. 430 BC) presented, cf. [1, 17:40-52]. Thus, the consequence was that the only thing that matter was the logical conclusion, and had nothing to do with the perception of the outside world. Heraclitus disagrees.

Several times, Heraclitus insists that humans are incapable of observing the truth: "Not comprehending, they hear like the deaf. The saying is their witness: absent while present" [29, (D. 34, M.2)]. Thus, only a few people can understand the real meaning of 
his philosophy. We can also see from the form and the style of his survived fragments and writing that those frequent skillful synthetic ambiguities embellished by linguistic density and resonance, are not just a matter of chance, but as a method to leave the ideas in obscurity in order to pass the knowledge of the truth to those whom deserve it.

However, how does this aforementioned fragment lead the philosophers to the truth of unity rather than instability and relativism?

Nowadays, Heraclitus is mostly discussed when considering his "doctrine of flux" which emerged from the famous fragment mentioned above. In fact, it was the unity in source not the matter of the change, which was important for Heraclitus. Considering the other saying of the Heraclitus and his whole systematic idea is unavoidably vital in understanding the truth about his esoteric writing.

Although this account [Logos] holds forever, men ever fail to comprehend, both before hearing it and once they have heard. Although all things come to pass in accordance with this account [Logos], men are like the untried when they try such words and works as I set forth, distinguishing each according to its nature and telling how it is. But other men are oblivious of what they do awake, just as they are forgetful of what they do asleep [29, p. 49].

According to this saying, we can be sure that Heraclitus argued about the truth that latent in Nature, which has been not yet accessed by anyone else. Here, what I notably emphasis is on the relation between nature and logos with the ration of the human being and the laws accordance with it. Despite his idea about the essence of the things, when he speaks about the truth, he purposely avoids any material aspects. Although the role of the fire is revealed in this account as the source of matter and its movement, Heraclitus has the idea of the Logos in his mind. This for him is on one hand an actual constituent, and on the other, the order and discipline of all. These two fundamental principles of Heraclitus thoughts can be seen very closely to the philosophical principle of Ancient Iranian religion called Zoroastrianism (ca. 1200 BC.), in which the fire respected as the essence of the universe and the Ahura Mazda (Illuminating Wisdom) and Angra Mainyu (Destructive Spirit) considered as two concepts of the immaterial order of the universe which are the Logos. (We will discuss these two concepts in Heraclitus' idea in the following text.)

\section{The Combination of Stability and Flux}

So, what is the Logos in Heraclitus thoughts? And can that actually lead us to the movement of attention of philosophers from Nature to the human beings? We must note that the word of $\lambda$ ó ${ }_{0}$ s (the Logos) first used by Heraclitus. From the direct translation, it is almost impossible to allege that this word is totally equal with "word", "speak" or "account". To consider the meaning of the Logos is to conduct epistemological research in the philosophical structure of Heraclitus's thought. Unable to directly translate the Logos, we are able to get to understand it from this point of view, that the Logos is shared or common in the whole:

Although the account is shared, most men live as though their thinking were a private possession $[29$, p. 29].

For Heraclitus, the notion of "the change" and "the movement" brought out another idea, which helped him to have a better view to the matter of the whole: the idea of uncertainty about the relativity of human judgments. This relativism was caused by the failure of the 
sense perceptions and continues to this day. Heraclitus stressed this point in the following fragment:

The sea is the purest and foulest water: for fish drinkable and life sustaining; for men undrinkable and deadly [29, D.61, M.35, p. 61].

However, he could not accept the absolute incoherency of the things, which stems from perceptions influenced by nature. The world was regarded by him as a world in Flux. However, he observed that what emerges from the relation between each component of the world is a systematic dependence. This idea was a departure point for him to say that:

The way up and down is one and the same [29, p. 75]

But with a view at the change.

What is interesting though is that, at the time he is arguing his doctrine of Flux, the characteristics of stability, on the one hand, and the superiority, on the other hand, were the most contentious one. The doctrine of Flux is assumed to represent an essential characteristic of Nature, that this essential element orders all beings from above and can be interpreted as a common principle in Heraclitus thought. Yet, we have to ask whether this common principle comes from nature or is the nature itself?

This is related to the assumption that "Nature loves to hide" [29, p. 33] and simultaneously to the assumption that "It belongs to all men to know themselves and to think well" [29, XXIX (D. 116, M. $15 \mathrm{f}=23 \mathrm{e}$ ) Stobaeus III.5.6, p. 41]. Later interpretations of the Heraclitus' idea abstractly ended to the idea of Natural Law or The Law of Nature. There are two fundamental features in natural law theory. One reveals the divine aspect of natural law, evinced in a way that it amputated this law from what today has been called 'positive law'. Positive law has been based on human decisions and traditions, for specific situations. The second is that, by considering the law of nature, there must be a de facto receiver of the natural law. The question is, what is the essential characteristic of the de facto receiver of this natural law? This question leads to the point that, the natural law is directly related the role of human intellect. In this view, human intellect works in accordance with this common law, as Heraclitus called it, or natural law, according to modern scholars. Its function is to receive the fundamental characteristic of the order. The practical faculty and its function, must be completely in accordance with what is observed within the process of understanding the Logos: the law that is common in Nature or the natural law. Thus, we have the Logos, on one hand, and the shared rationality [29, p. 43] among humans, on the other. The link between these two fundamental elements is the cornerstone of the movement that removes the attention from nature and put it back on human life. This movement caused a reorientation toward human role as an important element in nature and the right way of living in accordance with natural law. Hence, the man again has the faculty, with which to understand the Logos and even impose it on others- as a matter of authority and superiority. This is the most powerful link beneath the whole argument on the relation of Logos, human intellect and political life.

I have it clear how the attention of thinkers and philosophers changed and moved from the nature to the Logos and then from the Logos to the human beings - in respect to the point that the human being is regarded a part of the Logos. Now let us get back to the point of how this characteristic affected Isocrates' view. 


\section{Logos and Politics}

Orators and sophists moved the goals and considerations of the society with their attentive speech-plays. In this way, the idea of their predecessors got its new form. They came to the conclusion first, that logos should be regarded as one of the most important aspects in human life related to its roles and its place and with respect to its direct effect on human intellect, e.g. the faculty of language. This traditional notion of the Logos which portrayed it more as the $\delta v v \alpha \sigma \tau \eta \varsigma$ (dominant principle as a ruler and master) can be seen in Isocrates' Nicoles, [28, Sec.6-9], [19], where can be trace back to Geogias [19, p. 15] and then Heraclitus' first Fragment. Second, that there has to be a powerful intellectual receiver of the Logos. And third, by knowing the power of intellect, words became an instrument with which human beings can to do anything [19, p. 10].

From the historical perspective, the first and the second aforementioned conclusions stressed by famous Ancient Greek Philosophers, e.g. Socrates, Plato, Aristotle and also Stoics, while the third aforementioned conclusion strongly emphasized by the pre-Socratic thinkers due to political participation fevers and the high emphasis on the relation of the political decisions and the ability to speak. So, we can say that the deliberations on the first and the second conclusion were somehow later than the third one, in the process of political thoughts.

However, lets back to the philosophical discussion. The third conclusion is directly linked to the notion of the Logos which appears as the power of sovereignty, i.e.

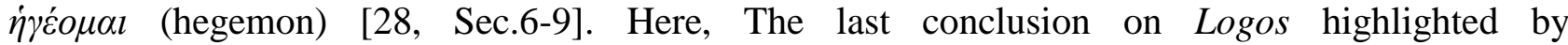
Isocrates. He illustrates the relationship between rhetoric and power based on the last notion of the Logos. Furthermore, by approaching to the $\dot{\eta} \gamma \varepsilon \dot{\varepsilon} \% \alpha l$ (hegemon) function of Logos, Isocrates allege that the principle of social harmony, and what he concerned with was the peace and unification of his Polis ${ }^{\mathrm{v}}$, would be achieved through rhetoric, viz. a true rhetorical skill with respect to the Natural law and Logos. This advantage related to the practice of faculty of language, which has its roots in Nature, where the mechanism of the Logos and humans intellect connected for the political order. Moreover, what makes the Isocrates works worthy is the principle of civic education and the values of democratic

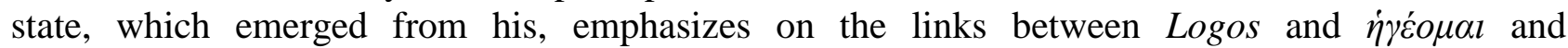
its effect in order to achieve the just ends. The hegemonic function of the Logos has been always accompanied by the teleological reasoning. Hitherto, these two fundamental functions help the political accomplishment through deliberation. Particularly, the combination of the strategically and tactically arguments in politics in Isocrates's school advantage to the democratic state; it will activated when a de facto faculty of language bring a positive outcome if it will be accompanied with Captatio benevolentiae's method in rhetoric in a political discourse among the citizens.

\section{Rhetoric and Politics}

In another view, rhetoric is the art of properly using language to persuade, an instrument. Oratory has been regarded as a part of rhetoric and recognized as skillfully speaking in public. Here, we have to ask what modern societies have learned or not learned from incipient ancient democracy. Undoubtedly, one aspect of social liberty, i.e. freedom of speech, and recognition of individual rights, freedom of conscious and security for their lives, are the core principles of modern democratic states in the matter of individual rights and freedom for expressing ideas. This can be partially observed in both eras. Beneath this surface, however, in Ancient Athenian society, public prominences were not often achieved by the free-will election of other people based on the logical consistency, but by using their elaborated language abilities to persuade the multitude to choose them. The 
ignorance of the right education depraved taste of the freedom of speech. Probably, in contrary to the freedom of speech as a common point between the modern democratic states and the ancient one, the right education is the most primary distinction between them on the matter of rhetoric. The distinction can be also related to the value-based logical argument in the modern state. What positively emerged from the rhetorical method of the Isocrates in favor of the logical-based argument in the modern state are the means of the critic, appropriation, and correction. However, The public prominences, during the emergence of second generation of sophists, were depended rather on one man's ability of oratory- that is here the ability to speak elaborately- how one can sway the majority of citizens in public debates presented in the Assembly, court, public gathering or feasts to vote or to give any consent in favor of one of the litigants [22], [17, p. 3]; or in a trial, vote for proposed courses of actions or a public movement toward a specific cultural change. Hitherward, the foundation of the democracy of the ancient Greek state laid down deep into some demagoguery.

However, a great deal of the notion of rhetoric, which shaped it as an valuable political activity goes back to the Romans and more importantly, to the Ancient Greece. By looking at the Homeric poems, one can see how this skill was vital and useful. Athenian leaders in the fifth and fourth century B.C., such as Pericles, Themistocles, Solon and Cicero, or political figures like the Romanian consuls were among those successful leaders who held the power of oratory and used this ability to preserve their place at the top [33]. Rise and fall of the rhetoric skills are not only related to one period, but it is the product of the historical process [36, p. 12]. In a world without any mass communication systems, without media, newspaper or television, let alone Internet blogs and other communication facilities, speaking in public was an essential element, if it was not the only one, of political participation and politics. The achievement in this field is not because of the communication facilities that we have in our modern days.

In ancient time, people traveled thousand miles to watch a public speaking competition or a speech from a famous orator/politician. The communication would play a key role, and what is important is that communication succeeds not because of the different technology's facilities, but because of the art of speakers and the deliberative connection that it makes between the specified circumstances and the audience through their logic and emotions. Communication indicates the common sense of deliberation and influence of logos in social life. It was in this sense that the orators/politicians were the rock stars of their time, and still they are. The art of oratory and the bond that it makes between orator and the people, this principle, still is a primary one in our modern society with which one can establish an intimate relationship with the audience. Thus, as it was, it is necessary to have experts of speaking skillfully in public debates and in politics. Since, this process is a natural process of systematic practice in the very culture of the political activity and its element is based on what the society consists of: the people as sociopolitical animals. Based on this idea, there would be possibility if we argue against some modern societies that have been growing experts in business or in military, because their main idea regarding success was restricted primarily to the high level of money making skills or security and war. The most contribution to the political progress is the critical mind of citizens, i.e. the political body of the state, and their effectiveness by their participation and simultaneously, their philosophical education. The range of negations in regard to the matter of encouraging, producing and criticizing the political activities is the cause of major ignorance on philosophical and rhetorical aspects of education that is more crucial for the modern democratic nation-states. 


\section{The Limitations and Weak Points of Ancient Greek Art of Rhetoric}

This comparative approach urges us to examine both sides of the subject. Thus, this aspect is a turning point for us to elucidate what consequences it has if the mere rhetorical skill regarded as the only required skill in the social-political activity. By showing this point, I will be able to lighten up the ideas that caused the difference between the first and the second part of Isocrates life. Moreover, it will indirectly help us to recognize the differences between the speeches that have been held today.

It seems that the oratory began with the daily activity of some people to tell stories for the public. This activity can be traced back to the early Homeric period. The art of telling stories, in the late Homeric period and after it, got its new way toward telling the histories as well. The histories mixed in the context of stories. Those who had the job as historians and poets usually spoke in the public places for presenting their works. Nevertheless, their works were in the narrative form and presented by a close imitation of Attic dialect [3, pp. 11-12]. By the outset of Ancient Athenian "democracy", these public speakers, by the mean of the historian, engaged in the interesting public political debates through their speeches. These speeches gain its advocates and became as logographoi. ${ }^{\text {vi }}$ Nevertheless, the next level of oratory was concerned at its early ages as a skill of speechwriting and as an activity to present these speeches in the public places. Hence, the link between two aspects of historiography and poetry helps orator to easily engage her speech with the current political debates. Thus, oratory built an interesting affiliation between the historiography, poetry, and democracy. However, this method has been always accompanied with reliance more on the emotional aspect of the speech. The relationship between historiography and political debates can be seen in the transition of the word $\mu v \theta \omega \delta \eta \varsigma$ (mythōdess) from "fairy-tale"vii to "flattering" in the patriotic political stories [16], [30, 11.1, pp. 35-39]. By entering the political debates in orators' speeches, the function of oratory got closer to the rhetoric one, yet it is still an open debate of our time.

With regard to the emotional aspect of the speech as the common weak point of oratory and rhetoric, the first critic of the early rhetoric principle, however, followed necessary by considering the logographoi. Most of the times, the combination of logographoi with oratory cause presenting untrustworthy account, because it is based on the unreal situation or at least combined with these situations. The most important inclination for orator to do so is, for instance, from avarice or from ambition to the pursuit of gain, which pointed out by Plato:

If anyone be held to be trying to reverse the course of just pleas in the minds of the judges, or to be multiplying suits unduly or aiding others to do so, whoso wishes shall indict him for preserve procedure, and he shall be tried before the court of select judges, and if he be convicted, the court shall determine whether he seems to be acting from avarice or from ambition; and if from the latter, the court shall determine for how long a period such an one shall be precluded from bringing an action against anyone, or aiding anyone to do so; while if avarice be his motive, if he be an alien he shall be sent out of the country and forbidden to return on pain of death, but if he be a citizen he shall be put to death because of his unscrupulous devotion to pursuit of gain $\left[11\right.$, Laws, $11.938^{\mathrm{a}-\mathrm{c}}$; emphasis added].

If we do not consider the element of democratic state here, still there is open to critics. What Plato does not count in this text, is how the liberty of speech in expressing the idea is crucial to the implement of the reciprocal argument in which the essence of the political participation latent. 
The second critic is that, usually the narratives that based on histories, which presented in public debates, have the lack of logics. Moreover, when this method of oratory entered the realm of rhetoric in democratic debates, initially used the communis opinio by presenting it back to the people. Here, the problem of $\delta \dot{\xi} \xi \alpha$ (doxa or the common belief of the demo) is one of the most contentious ones that almost every political theorist has been concerned about. However, it seems that at the same time this problem was one of the tools for being dominant in the speeches over the demo, the concept of 'power over' were fortified by the art of rhetoric. The question is whether it is a wicked ability or not, yet the rhetoric as a mere instrument will be justified with its moral significance which cannot be find intrinsically within it but in the action and aims of political actors. The modern example of this wicked ability in speeches can be found in every religious revolution. Even without the oratory skill, the instrumental usage of the doxa, viz. over-using the common belief or popular opinion of the people to achieve a certain goal, as the people persuaded indirectly, can be effective. Such aspect can be seen recently throughout the last few decades, which caused revolutions that took place namely in the Middle East. These are the major pragmatic political consequences. The result would be a strong encountering movement against the right form of rhetoric in religious or military regimes. Such antagonism of rhetoric education is due to the liberty principles that it requires and due to the democratic improvement changes that it will cause. We don't have to wait for such experience in recent years, Sparta for instance, expelled the orators through the legal mechanism of alien acts ( $\xi \varepsilon v \eta \lambda \alpha \sigma i \alpha)$ [36, p. 16].

The third critic of rhetoric is when it regarded as the mere skill of a statesman with considering the subject of the oratory. This critic is related to the historical fact and to the essence of its development. It stress on the fact that the rhetoric emerged in a culture of competition, normalized through the organization of the Greek Olympic Games and institutionalized in the heart of public debates. According to this idea, oratory has been always considered by its audience. There would be no oratory and rhetoric effort if there was not any gathering of people, and in follow, if there was not any communal consent about a debate, recognition of others and value in public deliberation. Hence, if an orator considers her function as a mere rhetoric function, she sees it in the concept of agonis (competition). This is dangerous for democratic Polis, nation-states, because if the power of persuasion be free from the moral values and its moral significant, it negate the modern law of the nature, the subjects (= either they are the audiences or other citizens) would be treated like those who be treated as competitors in a physical competition. Consequently, the sovereign or orator will see them as the subjects of manipulation and there will be a small place left for seeing his own good as equals to others. This point delicately showed by Plato. In this sense, Plato makes a taxonomical comparison between the athletics and rhetoric in Euthydemus when he talks about two Sophists:

First of all they are first-rate in fighting with their bodies and battling with all comers- they are themselves master at fighting in armors, and can make anyone else expert who would pay their fees. Next, in the battle of the law courts they are champions; they can compete themselves and teach others to speak, and they can compose speeches suitable to deliver in court [11, 271d72a].

Socrates, here, invoke the violation that lies beneath the athletics and armor competitions, then guides the argument to the point that those violation in the fighting which placed in the public debates $\left[11,273^{\mathrm{d}}\right]$. Thus, rhetoric as its function alone and as dominating its subjects in democratic Polis, can be recognized with the same principles and intention that can be seen is competitions and its competitors. 
The fourth critic of mere rhetoric is a teleological objection. Rhetoric is aimed to an end. That end, regarded to its mere method, is persuasion. With a presupposition that if the aim of persuasion through rhetoric is good for the society, rhetorical skills still insufficient by themselves to handle the "good" for the Polis. However, the end of rhetoric in the context of public debates must be regarded in a more far-sighted way. The end of rhetoric must be integrated with the end of the public debates. In this respect, the end of the public debates, through the art of how to address the debates, is in a way that the consequence will be in a favor of those who concern about that debate: the ruler and the citizens [11, Euthydemus, 289a- 291a].

The fifth critic is that because of the attractiveness of the speech to be listening to, orators have to adorn their presentations with passionate statements. Through this process, public speakers sometimes ignored the exaggeration, which arises from most of the passionate statements.

By following the element of the exaggeration, the other critic comes necessarily. The sixth critic is about essential element of human communication by practicing his faculty of language. This essential element, which has been sought in each investigation and argument, is truth. Just as the Sophists traveled from location to location, so too they traveled from idea to idea [36, pp. 24-25]. We cannot examine rhetorical speeches and judge about their validity in true or false category, if the Rhetorical speeches considered by the mere rhetorical essence. It means that considering rhetoric without wisdom and erudition is diverge it from the absolute and push it in the doxa realm. In this sense, rhetoric is Indifferent morally and philosophically to the content of the speech or argument, and this means that the orator is irresponsibility of the audience. This critic has the same root in the argument in the fourth critic. However, the first part of this critical perspective tries to ignore the philosophical aspect of the rhetorical act, exactly at the heart of its essence where rhetoric is indifference to the argument. Of course rhetoric has been used in different station of trails, different perspectives of one opinion and natural to the moral elements of the subjects, but through this doubles and ambiguity leis the foundation of being persistence on no singular perspective, trust to no given constitution and loyal to any political system or sovereignty. Pre-judiciary assumptions are contraries to the critical thinking. It has been taken for granted that a philosophical mind is adorned with the same characters, which has been found in rhetorical method.

\section{Isocrates, Leadership and Political wisdom}

Among the experts of rhetoric in Ancient Greece, there were some figures, who were not totally concerned with the fame or power, but had tendency for discovering the truth. They would not regard themselves sophists or orators. One of the best of them, as we have mentioned, was Isocrates (436-338). Isocrates recognized the weak points of the art of rhetoric and the problem of doxa in his society. He used one of his important dual critiques- critic on neglecting the truth and critic on exaggeration at the opening lines of his book Against the Sophists:

If all those who undertook to teach were willing to speak the truth and not make greater promises than they plan to fulfill, they would not have such a bad reputation among the general public $[22, \Pi]$.

This recognition guided him to change his position from being just an orator to a political thinker. However, because of his two side characteristics of his life, scholars hardly tend to make long-term survey on his school. In fact, his idea is not well known as well as Plato and Aristotle, but they are still the most influential ideas in practice. 
Isocrates was born into a prosperous family, but that was just the temporary economic situation. After the outbreak of the Peloponnesian War (431-404 BC), things had completely changed for him. His family ended up losing all of their money because of the war. He might have been a teenager when the Athenians voted in a 'very democratic way' for killing all male citizens of Thracian city of Scione: The siege of Scione (423-421 B.C.) [9]. In his youth, he became a biographer, and a speechwriter at a time when this profession was burgeoning. Thus, he made a lot of money, which contributed to fame and success. However, his ideas changed throughout this first period of his life. Similar to the other studies on the thoughts of any reformer in the history of mankind, we can certainly predict what his real intention was, especially when we understand that he did not regard himself as a sophist. This point is important since it was pretty common and popular to be a sophist in that time.

In the second period of his life, he was more inclined to engage in philosophy. His goal was neither to be eloquent in public affairs, with the genuine sense of rhetoric in practice, nor to be a sophist.

Isocrates was deeply concerned with improving the political realm. He desired to see Greece in a relatively good situation by the means of domestic and foreign policy [21]. The largest proportion of Isocrates' work contains political characteristics. He was concerned with a more philosophical and theoretical aspect of political life, which directs the pragmatic realm, and thoughts rather than presenting some fancy speech in order to become famous among the Orators. However, he still strongly believed that oratory matters, not because of its popularity, but because the state established and maintain, or even defended, through the skills of 'leadership'. And one of the main elements of a good leadership respected, as the power to shape or change the intended will of the society in a way that a leader aims to. That is impossible unless the leader be prolific by rhetorical adornments. However, is it possible without the strong hand in the deliberative element? If this is so, still there is a distinction between the rhetorical skill and the wisdom of the leader(s) and their virtue. It seems that Isocrates understood this principle as one of the important aspects of a good state, as it showcases the main and vital qualification of his ideal statesman and his thoughts about the essence of politics. Therefore, for Isocrates, "leadership" is always hanging upon a skillful eloquent man who has a de facto faculty of language and happened to be rightly educated.

However, one might object about the links between the Isocrates's theory of virtues and its relationship to the politics. The link between virtues and the art of rhetoric diverges the cornerstone of Isocrates' political idea from the later philosophers like Plato and Aristotle, that is his rejection on a strong distinguish between theory and practice. In Isocrates school education matters. However, the civic education regarded more as an art than practical knowledge and that leads to the unification of theoretical and practical wisdom for being a virtuous man. In other words, if the virtue in Isocrates school can be explicated as the art of rhetoric, then the boundaries between the philosophy and politics, and the notion between the practice and theory is obscurely twisted. Thus, the proficiency in the art of rhetoric can play a critical role to make anyone wiser. This is the main idea of recognizing the virtue ( $\dot{\alpha} \rho \varepsilon \tau \dot{\eta}$, Aretē) and art $(\tau \dot{\varepsilon} \chi v \eta$, Techne $)$ in different perspectives. Aristotle used this principle to distinguish between the wisdom ( $\varphi \rho o ́ v \eta \sigma \iota \varsigma$, phronessis), the good and the art of rhetoric. However, here we cannot discuss Aristotle's idea of rhetoric. So it will be a good complimentary work for this participation if one does that.

Traditionally, Isocrates, according to his emphasize on the importance of language and the art of rhetoric, has been called as a sophist, but it is an overly reductive way to think about his place in the tradition of western political philosophy. Like our famous Ancient Greek philosophersSocrates, Plato, and Aristotle-, he considered himself more as a political philosopher and thinker rather than an orator or sophists, and that elucidates the real intention of his endeavors. Whether his school is of thought contributed to the major trends in philosophy or sophistic tradition remains a solemn question of today.

It has been said, that around 390 B.C., he seriously considered writing and teaching as his primary activity [17]. In most of his writing, he set forth his ideas about educational, political and 
philosophical activities, which make him significant much like other important contemporary figures, such as Socrates. Isocrates wrote hoi politikai logoi [23, 260], [22, 21] and he explains in the summary of his career that he is dealing with "Greek, and royal and political affairs" [25, 11] How closely the life of the individual was in fact bounded up with that of the state, is unveiled in the common usage of the word $\pi o \lambda i \tau \varepsilon v \varepsilon \sigma \theta v i$, i.e. "to live as a citizen", instead of the bare term "to live". But in the fourth century B.C., the Athenians moved by the democratic intentions to the tumult participations and political sedition that provoked them to have more and more their own lives, selfishly pursuing their own business, and craving increasingly for the liberty to "do as they liked" for their self-preservation and self-promotion that ended most of the time in self-conceit. They lost the primary essence of a democratic state. Thus, they were living off the state rather than living for it and its ultimate end. It is not that mere "living in a city", viz. in a political community, prevents men from behaving like beasts toward one another, but living as a part of the city and persuading its ends, which included both the common good for the individual and the political community, is what makes human beings responsible citizens. This idea brought principles to the later democratic Athenian society, which was required fundamental changes in its constitution. This principle did not exist after or prior to civil society, but along with it and comes into attention with considering the debates about politicization. Isocrates saw political life as the humanizing element in the life of man, that which separates men from beasts, cf. [4,1253a 29], [12, pp. 104-109]. This idea has been used profoundly in Aristotle's theory of political community over the debate on the nature of human beings as a political animal [12].

However, Isocrates had used the same method of rhetoric, but in a private way as that was the most appropriate method for the sake of political improvement. He, just like Plato, established a

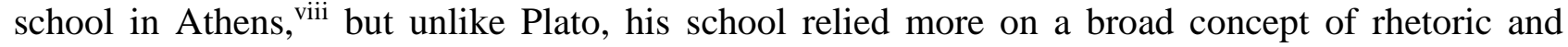
practical philosophy. So, his work on any metaphysical subjects faded in this respect. He was not gaga with philosophy in a way that would disparage the rhetoric, but he used it precisely in order to introduce and establish a right way of politics. These trainings consisted of rhetorical training and practicing for good political handling [37, pp. 2-4]. Because of this idea, the first task that his school engaged was those arguments Against the Sophists, which also served as an advertisement for his school.

In this way, Athenian history, particularly during the age between Socrates till the end of the Epicurean, is a very interesting age for a number of reasons. The State fought to be a good political state. From one side, it was the weightiness of decision that was being urged. The decisions were sometimes about war and peace, the other times were about capital punishment. Parallel with that disposition, on the other side, the intellectual debates were handed to those who were not interested only in public speech-contests, but were more concerned with all of the things under the title of Philsophia.

The intellectual community at that age was addressing the current ethical and political situations of Athens and its crisis hegemony and cohesion. We can see from the works, ranging from Isocrates's War and Peace and Against the Sophists, Plato's Laws and Republic to Aristotle's Ethics and Politics, that they tried to change the undergoing flow, which was happening in Ancient Athens. Furthermore, One of the problematical points was addressing the crisis of intellectual reasoning, i.e. being wise: the problem of Doxa and the other problematic points was the total participation of the masses in the political debates. The result of a combination of both problems was so-called autocratic of democratic participation that usually went out of hand when the masses participate in those situations that they were not entitled to. Since, the intellectual ignorance due to the rapid political upheavals causes the disorientation of the values and principles in every constitution. Facing these problems, what Isocrates tried to establish, in regard to the $\pi 0 \lambda i \tau \varepsilon v \varepsilon \sigma \theta v \imath$ was accompanied with the systematic democratic element of the education. Education transfers the demo, the people of a democratic state, which all they would have done without it, is to interference emotionally, the amenable individuals. Education provides a ground for equality of citizens in a democratic power relation and makes them apt to the deliberative political life [2]. This progressive 
method was aimed to change the society from an incipient intended will of corporation to a harmonized political nation-state. In this sense, the role of speech in the educational process, on the one hand, is derived from the natural rights of individuals, and on the other hand, is derived from the essence of political participation. In the modern nation-state, the entitlement of the political participation, however, is not depends only on the freedom of the speech, but also valuable in respect to the education that possible through the link between the rhetorical skill and the moral significance of actions. This is what Isocrates grasped and tries to use it in his reformative school.

Although, there are some differences in the practical realm, between Isocrates' idea about the knowledge and those of Plato and Aristotle's, It is hard to believe that Isocrates' idea of wisdom based on an opinion that leads to the conclusion that there is no exact knowledge that can lead a man to what to say or what to do. Rather, in his view, the opinion (doxai) coupled with the doctrine of situational judgment as a character of a statesman, which has to have its roots in the practical wisdom, are respected as the only way for being wise [23, 271], [25, 28-29]. However, Isocrates believed that in some point, eliminating the problem of doxa or ignoring it are not the correct remedies, but guiding the community's doxa through the rhetoric and education necessitated the changes within the problem. Hitherto, we can see that his school is not a completely philosophical school like those of Plato and Aristotle but is not a mere sophistical one either. However, as it has been delineated before, he was a thinker who was only concerned with practical action. At some point, the practical actions relate strongly to the particular situations. At least, it can be assumed by considering the striving of the Isocratic, that is the core idea of his philosophy from his general statements, especially with a view to Against the Sophists. On the one hand, he could neither be thoughtless, conventional, and lumpen, on the other hand nor has he faced the rigors of what had been totally concerned by philosophers. His criticism in Against the Sophists considered several points against thoughtlessness and conventionalism of his society. The criticism of:

(i) Sophists acts in order to make big speeches in order to teach others to be a great deceiver under the cover of teaching to be a great leader,

(ii) Unrealistic claims

(iii) Generalized the specific rules and presented it in handbooks,

(iv) Being a business man rather than who work for the improvements of the society in both levels of itinerant and high fees sophists and

(v) Forensic rhetoric, due to the fact that, they were trying to encourage litigiousness rather than solving problems.

First, as an orator and second, as a political theorist, he tried to make harmony between rhetoric and philosophy, and then between the masses and the elites. His main goal was remained to use philosophical methods in the practice of leadership in order to bring "peace" to the Polis. This is so familiar a doctrine for modern democratic state, that the fundamental principle of it has made me pass by, without their due reflection, the cohesion structure of education and essence of the democratic state, i.e. liberal principle on freedom of speech, in respect to the life of citizens, on the one hand, and the harmony of the state and the virtue of the leadership, on the other.

Moreover, Isocrates's Antidosis is a good work to start with, because in this book, Isocrates criticizes the opinions of his fellow thinkers. In answering his critics, he revealed the true intention of the Sophists and compared their goals to his own. In this way, he critically diverged from the Sophists. He had done an important job through his work Antidosis and Against the Sophists, as he determined his position as a political theorist. This idea can be regarded as the first step toward the intellectual reform during the 5th and 4th century B.C. The idea can be basically interpreted as: Not going with the flow. However, Isocrates' attempts highlighted the difference between himself and other, so called thinkers, but that was not the only goal of his doctrine. In this sense, he 
presented the doctrine on "peace" and "unification" of Athenian society, which must be surveyed more deeply.

\section{Peace and Security: A Lesson from Isocrates}

Isocrates was trying to conceal the individual life with the good of the state in the whole sense, but he did not mean that an individual way of life is superior to the common living of his fellow citizens. Unfortunately, he did not develop this idea in an elaborated form, as subsequent philosophers such as Plato and Aristotle did. For him, the end of political life and the end of the Polis, would be directly related to the soul of the Polis by which citizens are the primary elements [23, 21-23]. The relationship of the individual and the state- both aspects of metaphysics and practices- is vital to the process of reaching a good life and maintaining it and can be seen more vividly in the works of Plato and Aristotle.

As a teacher, Isocrates was more concerned with the political aspect of the individuals in the state, rather than a theoretical one, let alone fight for a pure eudaimonia in a sense that our philosophers -Plato and Aristotle- meant. He sought for the peace between the elite in a "few" sense and ordinary people in a "wide" sense; aka the wise and the ignorant. This style of education almost worked in the Athenian state, where, albeit of the democratic fever, there was little tolerance for Monarchy. Couple with this highly intoleration ambiance, there was an implicit ignorance among the multitude, which the ignorance has adorned by the ambitious element. Supposed that, Isocrates had to discursively contend the ideological hegemony of demos [23, p. 34]. This character can be seen elsewhere among those who believed excessively in democratic ideology or on discriminating authority [15], [13]. Isocrates, as I argue, is the founder of the synthetic between the (i) rhetoric and philosophy, (ii) patriotic and cosmopolitan discourses and (iii) the principle of the democratic and the aristocratic society. The combination of these heterogeneous plays the main role in his doctrine to make the peace, harmony and integrity of his society. What is interesting, though, is that they are determined as the ingredients of the foundation of the modern societies. However, the modern democratic state is more close to the toleration and wisdom. This element is the central diversion point between the ancient and modern democratic state, which directly takes effect from two aspects of the education and the rhetoric skills on the people. Hence, the right government, which established on the mottos of "of the people, by the people and for the people", shall well execute the rhetorical skill and well exercise the just education based on the liberty of the speech.

\section{Ambiance, Method and Idea}

The main components of Isocrates's ideas, just like all other political thinkers, are the Polis and its citizens. He, at the end of the shameful and disgracing Athenian "Social War", which was about Athenian confederacy and its colonies (355 B.C.), was concerned with the republic life; and the matter of its safety [24, 140:2] and its relation to the Polis itself. Indeed, when one is concerned with the relationship between Polis and its citizens, "the best order", the form of power relation and power structure, comes into question too.

Isocrates was not completely against the idea of democracy because democracy allowed him to speak without fear [24, 143:17]. He was, however, hoping for a different kind of democracy. Thus, despite his strong critical opinion against the democracy of his time, unlike Plato and, this is the key point, he thought that democracy was a way that a Polis can be perfectly ruled too. And more importantly, he did not argue against democracy as a solution to the current crisis of his time, rather he refers to the [good] "earlier democracy, which was instituted by Solon and re-established by Cleisthenes." 
[24, 143]. According to what have been hitherto mentioned, we can see the link between his ideas of a good city with the one that those early famous rulers tried to establish as justified democratic state.

The date that the word "democracy" was invented in the history of mankind, is relatively unimportant, but the forms of democracy should be an important matter to understand its meaning, its process and its goals. These are the three aspect of a state legitimacy: input, throughput, and output legitimacy. There is no issue "where?", because, of course, it happened in the Polis of the Athenians. What is important, though, is that, the democracy in Ancient-Greek-style was extremely different from ours, in structure, its process and its telos. More important is that, when we are speaking about that moment, that the democracy we referred to, was a newfangled democracy which emerged from some styles of so called "ruled by some", which I would call it "the pre-Socrates Aristocracy'. The nobility, myth, divine law of oracle and the imaginary glories of the Homeric poems were losing its authority [42, pp. 104-25], cf. [36, p. 13]. The sophistical reforms of the first and second generation led this age to two different direction of establishing a democratic state, two different form of democracy. One was carrying the demagogy element under the democracy's name, the other was carrying the right to the public deliberation for all, and insistence on possibilities on rethinking on laws under the two condition of rights to freedom of speech and public education, the concept of organic law or living constitution. These are the radical idea of that time that has been taken for granted today. It is based on such historical process, which led to what we have today as Representative Democracy.

However, Isocrates was critically concerned about the movement that led them to the right democracy. That democratic idea must go back to the representative democracy or in some point to the Aristocracy, but in an esoteric form. One might ask: why in esoteric form? Because of the intolerance of the ordinary people that would cause the revolution, instability and anarchy in the political community. We learn from them that the capacity of a society hinged upon the education, so as its democratic characteristics. A blink at the Middle East countries, one may wonder how come the democratic process is so low? May what we have presented here would be one of the main answer to such question. Another reason that approves our claim is related to the existence of tones of Isocrates' opponents. At least, it has been clear from the appearance of the words that he has been talking about the democracy, using this term as same as other political thinkers at his time, but it can be seen also that he portrayed himself as existing within and contending with huge critical voices. He actually receives attacks upon himself, his profession and his proposed Polis, but Why?

When we try to illustrate the situation with a simple example, we can imagine that there is a boat which heads to island X. Perhaps somebody among the passengers shouts out that we should go to the island $X$, then he faces lots of opponents against him. If the boat is going to island $\mathrm{X}$, the reason of the opponents' voices can be several:

1) The boat does not go to island $X$.

2) The opponents are not aware that the boat goes to island $X$.

3) The island $X$ has another meaning - here is another place- than what the others think.

In a fever of democratic society among each one of the population of the Athenian, was not that strange and anomalistic to talk about the democracy. That elucidates us how Isocrates meant something else, even though he used the term of democracy several times. His democracy was different with the ancient Greek democracy, just as the difference element that can be found between the Ancient and modern democracy. On the other hand, the critics which were on him indicate the separation of him from his 
contemporary thinkers. Although, Isocrates had done all and he regarded his effort as a remedy for a situation so momentous, i.e. the present situation of Athens; and he hoped that his work would be an inspiration for the future, but not at any rate remains as just "oracle for the future" [26, 171].

\section{Modern rhetorical approach}

In the modern stand out political theories, there are two major approaches to the ancient Greek rhetorical tradition. One is an ideological critic, which is mostly applied by the temporal judgments of exegetical methods and the other is the human agency in the Polis, which is more relied on the analytical approach. It is important to note that the ideological critic must not be applied by the judgment about the past through the valuation of the present. Most of these failures come from the dark sides of the racism, elitism and sexism that happened in the historical through extreme movements and leads scholars that Greek rhetorical tradition had nothing in essence to present to us for our modern society. In fact, there are two movements in our modern political philosophy against this failure.

One of the movement is the way to recast the rhetorical endeavors, as Isocrates tried to, to present them as they are not for flattering the audience $\left[11,463^{\mathrm{a}}\right]$ or they are not to teach them how to gain domination in conflicts, but to recast them as the way to educate the citizens the art of citizenry by giving them the ability to deliberate and participate in the political realm. Gradual challenging sprite of each argument, if it based on the right principles, is based on the intellectual tradition of the sophists/philosophers. This method, which revived as the consequence of the ancient Greek philosophicalrhetorical tradition has been moved the modern political societies to the more solid nation-states [43], cf. [41, p. 92]. Since, such ability coupled with the right education that cause the awareness level of the participants improve several established discursive practice and consequently, improve outcome of such discourses, which helps the political community in its virtues, justice and liberty foundation.

The other movement is to show that how the rhetorical endeavors are important to the civic education when these endeavors combined with the political, philosophical context. The civic education lead Polis, or the modern nation-states, to be more harmonized and make citizens obey the just law by the art of self-consciousness, political consciousness, and historical consciousness. This democratic commitment to the state is the consequence of the rhetorical-philosophical education, elaborated by the modern concept of society and its components. This character can be found in modern works like S. Jarratt's Rereading the Sophists (Carbondale, Ill: 1991), C. Glenn's Rhetoric Retold (Carbondale, Ill: 1997), J. Atwill's Rhetoric Reclaimed (Ithaca: 1998), J. Kastely's Rethinking the Rhetorical Tradition (New Haven: 1997), V. Vitanza's Writing Histories of Rhetoric (Carbondale, Ill: 1994), and Poulakos' Rethinking the History of Rhetoric (Boulder, CO: 1993) [41, p. 18].

However, how rhetorical practices in society can shape the intellectual ability in social activity and how education can shape the rhetoric principle for the sake of establishing and maintaining of what we call it today as the liberal and democratic state, was the cornerstone of Isocrates thoughts. This point is still in the center of attention for those who examine the rhetoric in relation to the civic education.

With a great survey on Isocrates ideas, maybe compare to the schools of great philosophers like Plato and Aristotle his school seems trivial at a glance, but in itself, it has been found wanting.

However, reading Isocrates cause us to encounter several difficulties. One of them is for the essence of the "speech", simply because most of his works are speeches, they are only partial expositions of a man's reason for a specific perspective of the world. However, they seem that they are incomplete in structure, as they are directed to one particular audience or particular situation of 
that time and this is an important point because he did not attempt directly to address the general predicament for having the best Polis with noble citizens. We can see in Plato and Aristotle views that the whole can be reconstructed only from a view of the whole, but that whole is not supplied by a speech as speech, which simply related to a particular situation. Todays, hence, the democratic state shall focus more on the educational aspect of the philosophy rather than the rhetorical aspect, although one of the main manifesto of the liberalism i.e. freedom of the speech, can only nourished and empowered by the rhetorical skill.

The second difficulty is that, how closely any passage may be identified with the author's own opinion has been always a question and it requires a great endeavors from interpreters to find that out. It is not a sure thing to say, Socrates in the Protagoras can be identical with Plato's own views. Similarly, it is not justifiable to accept Isocrates statements in conventionalized speeches to the Athenian Assembly as his genuinely ideas. Moreover, the distinction between the works related to the first period of Isocrates' life and the works related to the second part is unavoidable to understand Isocrates real doctrine. As per the aforementioned reasons, it can be seen that his writings could not have that easily apprehensible character granted to those whose goals have a more immediate specificity and clarity. However, Isocrates can be a great resource in the practical aspect of the rhetoric skill and esoteric teaching of the representative democracy.

The third difficulty is that, despite of all predicaments to interpret rhetorical speeches as the own ideas of their writers; we can argue that Isocrates deeds and works was aimed, in some point, to make the citizens of the Polis, good citizens [27, 3-5], [25, 87]. Though, not the art of speaking, but a combination between education and rhetorical skill which are the cornerstone of Isocrates school can be considered as the main elements of his idea to the progress of political situation of his time. Regarding the similar impact of this combination on all political ages, highlighting the importance of it in the education system and among the politicians, when the concern is with the better political life of the welfare of the citizens in the liberal democratic states. If we use the rhetoric, as Isocrates emphasizes, as a reflective, aesthetic deliberation which manifests into the political discussion, we have to recast philosophy as the other wings of this flight in out liberal education to have a just modern democratic society that one of its main focus is humanistic education in relation to the civic virtue and civic activities.

In this way, we can see Isocrates as one of the important figures in the history of western political philosophy. Hence, our focus on rhetorical aspects of political philosophy must not limited in fifth and fourth century. There are centuries of late Greek and Roman rhetorical-political theories that related to our modern political one and they are still must to be explored.

\section{Conclusion}

It has been elucidated that the culture of the political activity and its element is based on what the society is consists of: the people as socio-political component and the political principles of a power structure. Both of them under the rational-normative principle can be the foundations of the relationship between people and the state. In this respect, philosophical and rhetorical aspects of political education are one of the main causes of politicization and flourishing of democracy. This aspect in education seems crucial for the critical minds of citizens and the life of modern democratic states.

The correlated emphasis on this matter accrued in Isocrates works as the initial point of all critical thinking in politics and that was for the sake of improving the political regime. This progress has been always accompanied with emphasis on two aspects: the skill of leadership, and the skill of rhetoric. However, as Isocrates highlighted, 'leadership' is always hanging upon another skills such as being eloquence in language or having a de facto intellectual power. This is because man's nature is consisting of faculty of language. In this sense, the importance of language, or in the other word, the power of critical thinking, is knitted, on the one hand, to the nature of human being, i.e. intellectual being; and on the other hand, to its function, i.e. political active as a citizen. That is 
how Isocrates recognized the difference between the word $\pi \circ \lambda i \tau \varepsilon v \varepsilon \sigma \theta v \imath$ i.e. 'to live as a citizen', instead of the bare term 'to live'. Both of such concepts are pertaining to the concepts of political power: 'power over' and 'power to'.

Moreover, Isocrates' main objective, which emphasized on the philosophical methods in the practice of leadership in order to bring 'peace' to a political structure is conversantly correlates the doctrine of the toleration and wisdom in modern democratic state. This aspect is an assessment to the third concept of power as a combination of last two which emphasis on the autonomous will, 'power of'. However, I have argued that this aspect requires more political practice these days. Furthermore, in the realm of theoretic, the other movement is to show that how the rhetorical endeavors are important to the civic education when these endeavors combined with the philosophical context.

The democratic commitment to the state is the consequence of the rhetorical-philosophical tradition. This tradition elaborated by the modern concept of nation-state and its components in different aspects, such as how rhetorical practices in society can shape the intellectual ability in social activity and how education can shape the rhetoric principle for the sake of establishing and maintaining of, what we call it today as, the values of liberal and democratic states. It has been presented as the ground that how the Ancient theatrical theories of politics and practical practices of oratory $\left[11,659^{\mathrm{a}-\mathrm{c}}\right]$ are adorned with the modern intellectual discussion, cultural practice, citizen intercourse and positive deliberation. Moreover, Along with this intellectual flourishing and progress, it has been illustrated that the rhetorical analysis is the critical thinking, and it is one of the main component in preservation of the notion of human beings, which is the under-going intrinsic values of each human societies.

\section{Acknowledgement}

I wish to express a sincere gratitude to Prof. Dr. Anne Eusterschulte, Andrew Schumann, Konrad Szocik, and the editorial team of Studia Humana for their thoughtful comments on the earlier draft of this article. I would also like to thank my friend, Nathan Delaney, for all his help and kindness to prepare the earlier drafts.

\section{References:}

1. Abraham, W. E. The Nature of Zeno's Argument Against Plurality in DK 29 B I, Phronesis, Vol.17, Issue 1, 1972.

2. Allen, D. and Rob Reich. Education, Justice, and Democracy, Chicago: The University of Chicago Press, 2013.

3. Ameringer, Th. E. A Study in Greek Rhetoric. Washington: Catholic University of America, 1921.

4. Aristotle. Politics. Trans. by Jonathan Barners. Princeton: Princeton University Press, 1995.

5. Aristotle. Politik, Trans. by Franz Susemihl (Germany). Homburg: Rowohlts Verlag, 1994.

6. Aristotle. Physics. Trans. by William Charlton. Oxford: Clarendon Press (Clarendon Aristotle Series), 1992.

7. Arnason, J. P., Kurt A. Raaflaub, and Peter Wagner, (Ed.), The Greek Polis and the Invention of Democracy: A Politico-cultural transformation and its interpretations, West Sussex: Wiley-Blackwell, 2013.

8. Bizzell, P. and B. Herzberg. The Rhetorical Tradition: Readings from Classical times to the Present. Boston: Bedford of St. Martin's, 1990.

9. Campbell, J. et al. A Universal History: From the Earliest Accounts to the Present time. Volume V., London, 1759. 
10. Chisholm, H. Encyclopedia Britannica, London, 1910.

11. Cooper, J. Plato Complete Works. Indiana: Hackett Publishing Company, 1997.

12. Copeleston, F. C. A History of Philosophy. New York: Bantam Doubleday Dell Publishing, Inc, 1993.

13. Dahl, R. Democracy and its Critics. New Haven: Yale University Press, 1989.

14. Diels H. and W. Kranz (eds.). Die Fragmente der Vorsokratiker, 6th ed., vol. 2, Berlin: Weidmann, 1952, rpt. Dublin 1966. (Compilation (C1992 by the Regents of the University of California).

15. Downs, A. An Economic Theory of Democracy. New York: Harpercollins College, 1957.

16. Flory, S. The Archaic Smile of Herodotus, Classical Philology, 1990.

17. Gagarin, M. The Oratory of Classical Greek: Isocrates I. Vol.4, Texas: University of Texas Press, 2011.

18. Gomperz, T. Griechische Denker: Eiene Geschichte Der Antiken Philosophie. Vol.1. Berlin, 1922/73.

19. Georgias. Ecomuim of Helen. Trans. by Brian R. Donovan, 1999.

20. Guthrie. W. K. C. The Sophists. New York: Cambridge University Press, 1977.

21. Isocrates. Trans. by George Norlin, Vol.II. London: William Heinemann LTD, 1929.

22. Isocrates. Against the Sophists. George Norlin. Cambridge, MA: Harvard University Press; London, William Heinemann Ltd, 1980.

23. Isocrates. Antidosis. Trans. by George Norlin. Cambridge, MA: Harvard University Press; London, William Heinemann Ltd, 1980.

24. Isocrates. Areopagiticus. Trans. by George Norlin. Cambridge, MA: Harvard University Press; London, William Heinemann Ltd, 1980.

25. Isocrates. Panathenaicus. Trans. by George Norlin. Cambridge, MA: Harvard University Press; London, William Heinemann Ltd, 1980.

26. Isocrates. Panegyricus. Trans. by George Norlin. Cambridge, MA: Harvard University Press; London, William Heinemann Ltd, 1980.

27. Isocrates. To Demonicus. Trans. by George Norlin. Cambridge, MA: Harvard University Press; London, William Heinemann Ltd, 1980.

28. Isocrates. To Nicoles. Trans. by George Norlin. Cambridge, MA: Harvard University Press; London, William Heinemann Ltd, 1980.

29. Kahn, Ch. H. The Art and Thought of Heraclitus. Cambridge: Cambridge University Press, 1979.

30. Karagiannis, N. Democracy as a Tragic Regime: Democracy and its Cancellation, Critical Horizons. Vol.11, Issue1, 2010.

31. Lexicon Thucydidaeum: A Dictionary, in Greek and English, of the Words, Phrases, and Principal Idioms, Contained in The History of Peloponnesian war of Thucydides. London, 1824.

32. MacIntyre, A. A Short History of Ethics: A History of Moral Philosophy from the Homeric Age to the Twentieth Century. Routledge, 2002.

33. Mirhady, D. C., Y. L. Too. (Trans.) The Oratory of Classic Greek: Isocrates I. Texas: University of Texas Press, 2001.

34. Sale, G. et al. A Universal History: From the Earliest Accounts to the Present Time. USA: Nabu Press, 2011.

35. Plato. Theaetetus. Ed. By Edith Hamilton, New Jersey: Princeton University Press, 1994.

36. Poulakos, J. Sophistical Rhetoric in Classical Greek. University of South Carolina Press, 2008.

37. Poulakos, T. and D. Depew. Isocrates and Civic Education. Texas: University of Texas Press, 2004.

38. The Holy Bible, Douay -Rheims Version, 1989. 
39. Thucydides, Lexicon Thucydidaum: A Dictionary, in Greek and English, of the Words, Phrases, and Principal Idioms, Containe ${ }^{i x} d$ in The History of Peloponnesian war of Thucydides, London: G.B. Whittaker., London, G.B. Whittaker, 1824.

40. Too, Y. L. The Rhetoric of Identity in Isocrates: Text, Power, Pedagogy. Cambridge [England]: Cambridge University Press, 1995.

41. Worthington, I. A Companion to Greek Rhetoric Blackwell Companions to the Ancient World. Blackwell Publishing, 2007.

42. Wilkerson, K. E. From Hero to Citizen: Persuasion in early Greece. Philosophy and Rhetoric, Spring, 1972.

43. Yunis, H. Taming Democracy: Models of Political Rhetoric in Classical Athens. Ithaca: Cornell University Press, 1996.

\section{Notes:}

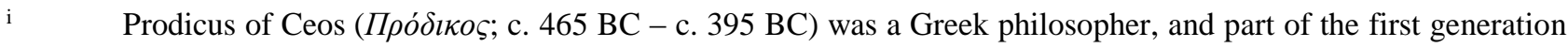
of Sophists. He came to Athens as ambassador from Ceos, and became known as a speaker and a teacher. Plato treats him with greater respect than the other sophists, and in several of the Platonic dialogues Socrates appears as the friend of Prodicus.

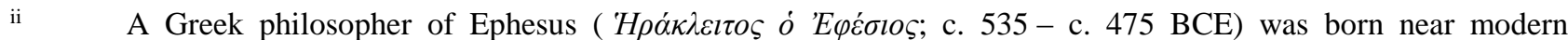
Kuşadası, Turkey, but not Athenian, who was active around 500 BCE;

iii For instance, the domination of deontological virtue between $17^{\text {th }}$ and $20^{\text {th }}$ century.

iv Pánton: genitive plural of the adjective "pas"(masculine), "pasa"(feminine), "pan” (neuter) meaning “all”/

"whole"/ "every")= of all things

v See also the discourse of panhellenism.

vi Logographoi is a method of pre-Herodotian historians.

vii German: Fabelhaft, Sagenhaft

viii Isocrates was born in 436, Plato in 429. 